\section{Kustamonu Eğitim Dergisi Kastamonu Education Journal}

Ocak 2019 Cilt:27 Sayı:1

kefdergi.kastamonu.edu.tr
Başvuru Tarihi/Received: 07.12.2017

Kabul Tarihi/Accepted: 02.04.2018

DOI: $10.24106 /$ kefdergi.2445

\title{
Özel Gereksinimli Küçük Çocuğu Olan Annelerin Öz Yetkinlikleri, Yılmazlık Düzeyleri ve Stres Düzeyleri Arasındaki İlişkilerin Belirlenmesi
}

\section{Identifying The Relationships Between Self-Efficacies, Resilience Levels, And Stress Levels of Mothers of Children with Special Needs}

\section{Öz}

\author{
Özlem ALTINDAĞ KUMAŞ ${ }^{1}$, Halime Miray SÜMER²
}

Bu çalışmada özel gereksinimli küçük çocuğu olan annelerin öz yetkinlikleri, yılmazlıkları ve stres düzeyleri arasındaki ilişki ve buna etki eden değişkenler incelenmiştir. Araştırma grubunu Ankara ilinde bulunan gelişimsel yetersizliği bulunan çocuğa sahip olan 150 anne oluşturmaktadır. Yapılan analizler sonucunda öz-yetkinlik toplam faktör puanı ile yılmazlık toplam faktör, yılmazlık faktör 1(mücadelecilik), yılmazlık faktör 2 (öz-yetkinlik) ve yılmazlık faktör 3 (yaşama bağlılık) puanları arasında, stres toplam faktör ile tüm stres faktörleri anlamlı ilişkiler bulunmuştur. Öz yetkinlik ve stres arasında ise tüm faktör puanları arasında anlamlı ilişkiler bulunamamıştı. Anne eğitim ile öz-yeterlik arasında ve gelir düzeyi ile öz-yeterlik, stres ve yılmazlık arasında anlamı farklılıklar bulunmuştur.

Anahtar Kelimeler: Yılmazlık, öz-yetkinlik, stres, özel gereksinimi olan çocuklar, anneler.

\section{Abstract}

This study analysed the relationship between self-efficacies, resilience levels, and stress levels of mothers of children with special needs and the factors that have an impact on these issues. Within the scope of this study, 150 mothers of children with developmental difficulties in Ankara were analyzed. The analysis showed significant relationships between self-efficacy total factor score and resilience total factor, resilience factor 1 (fighting spirit), resilience factor 2 (self-efficacy), and resilience factor 3 (joy for life) and between the stress total factor scores and all stress scores. No significant correlation was found among all factor scores between self-efficacy and stress. According to the result of the analysis, there are significant differences between a mother's educational level and self-efficacy, income level and self-efficacy, stress and resilience.

Keywords: Resilience, self-efficacy, stress, children with special needs, mothers. 


\section{Extended Summary}

The purpose of this study is to analyze the relationships between self-efficacy belief and resilience perception of mothers of children with special needs and between self-efficacy, stress, and resilience of mothers. Since mothers are more sensitive towards and more acquainted with children with special needs, they were identified as the subject of this study (Kaner, 2004). This study is of great importance since it is the first in Turkey to analyze the self-efficacy, stress, and resilience levels of families of children with special needs all in once. In order for services to be provided to children to be effective and to plan response and educational services accordingly, we first have to analyze in detail the needs of the family, its functions, challenges it is facing, its coping mechanisms, and the interactions among these elements (Kaner, 2004). Therefore, we are hoping this study to serve as a guide in getting informed about the self-efficacy, resilience, and stress levels of families of children with special needs and providing the necessary support and educational services to these children. This study is also believed to be important since it will be a leading study in Turkey on self-efficacy and resilience levels of mothers with or without children with special needs and it will provide data for future studies on this topic.

The study firstly made a descriptive analysis of the scores of mothers of children with special needs from stress, self-efficacy, and resilience scales. The study identified low self-efficacy, stress, and resilience levels of mothers of children with special needs. This finding of the study is supported by various studies analyzed in the literature Bootroydy, 1997; Hasting and Brown, 2002; Kandari, 2005; Seybold, Fritz and MacPhee, 1991; Kaner, Şekercioğlu and Yellice-Yüksel 2007; Scheel and Rieckmann 1998). For example, the study of Kaner, Şekercioğlu and Yellice-Yüksel identified that self-efficacy beliefs of mothers of children with mental, auditory, physical, etc. disabilities were lower than of parents of normally developing children. In their studies, Boothroyd, (1997) and Kandari (2005) identified that mothers of children with developmental disabilities had low levels of self-efficacy perception and high levels of stress due to low self-confidence in their ability and capacity to take care of their children. In studies conducted by Friborg, Hjemdal, Rosenvinge and Martinussen in 2003; Kaner and Bayraklı in 2010; Kaner, Bayraklı and Güzeller in 2011 mothers of children with special needs had lower levels of resilience. It was identified that negative attitude towards children with special needs, the fact that they require more care and attention, and concerns regarding the future of these children affected the resilience, self-efficacy, and stress levels of families (Kaner, 2009; Martinussen, 2003, Seybold, Fritz and MacPhee, 1991).

The study also analyzed the relationship between self-efficacy, resilience, and stress levels of mothers. In general, it resulted in significant relationships between the resilience and self-efficacy of mothers. Since faith in self-efficacy in case of a challenge makes people more resilient and resilience includes self-efficacy, it is evident that high self-efficacy has a positive effect on resilience (Rutter, 1987). While mothers, who do not strongly believe in their self-efficacy, experience high levels of stress, mothers with high self-efficacy avoid any burden that insults the self and thus have less concerns and experience less depression (Kwok ve Wong, 2000). In parallel with the literature, this study found a negative relationship between the stress levels and self-efficacy of mothers of children with special needs (Coleman and Karraker, 2000; Jones and Prinz, 2005; Scheel and Rieckmann, 1998). However, a significant relationship was only identified between the factor on the characteristics of the child, which is a stress sub factor, and self-efficacy factors. When we take a look at the items on the characteristics of the child in the stress sub factor, we see both the insufficiency of the child's functions and the problems parents face regarding their children's integration into the society. A great majority of children with special needs included in the study group was children diagnosed with mental disabilities. The study showed that highest level of stress and low self-efficacy belief was of mothers of children with mental disabilities (Kaner, 2004; Rodriguez and Murphy, 1997). It was also reported that families of children with special needs face negative attitudes and behaviors such as not being accepted in the society, even being mocked, pitiful, feared, and rejected, raising the stress levels of parents (ÖziDA, 2009). These may be the reasons behind the significant relationship between the factor on the characteristics of the child, which is a stress sub factor, and self-efficacy factors.

Also in the study, whether dependent variables had a significant difference in terms of maternal educational and income level was analyzed. The analyses showed significant differences in terms of stress levels, resilience and self-efficacy between mothers with low income and with middle and high income. In terms of level of impact, income level had a medium level impact on stress, resilience, and self-efficacy. In terms of self-efficacy, university-graduate mothers did better than primary school-graduate mothers. These findings are in parallel with the literature. Previous studies showed lower stress and higher self-efficacy and resilience as income and educational levels got higher. It is evident that a children with special needs brings additional burden on the family's shoulders. Many negative facts such as families being stigmatized and marginalized by the society due to having a disabled child, parents' lack of knowledge on the care and development of the child, low educational levels of parents, families' need of emotional, financial, and social support, and not being able to have access to such support result in low self-efficacy of families (Coleman and Karraker, 1997; Gutman, 2008; Seybold, Fritz and MacPhee, 1991; Hassall, Rose and McDonald, 2005). Therefore, families with low income and educational level face more stress due to the factors mentioned, affecting their self-efficacy. 


\section{Giriş}

Aile sistemin düzenli işleyişi için sahip olunan aile üyelerinin sorumlulukları göz önüne alındığında, özel gereksinimli bir çocuğun varlığı, aile sistemindeki dengeyi bozabilir. Bu durum ailelerin duygu ve düşüncelerini olumsuz yönde etkileyerek yüksek derecede stres kaynağı oluşturmaktadır (Cushner-Weinstein ve ark., 2008; Küçüker, 1997). Ailelerin yaşadığı stres, yalnızca çocuğa bakma yeteneğini olumsuz etkilemekle kalmamakta, aynı zamanda kendilerinin zihinsel ve fiziksel sağlığını ve çocuklarıyla olan ilişkisinin kalitesini etkilemektedir (Peer ve Hillman, 2014). Bu aileler, aile yaşamını çocuğun gereksinimleri etrafinda düzenlemek zorunda kalmakta ve çocuğu aşırı koruma ya da engeli inkar gibi durumlar yaşamaktadırlar (Küçüker, 1997). Çocuğun durumuna ilişkin yeterli bilgive sahibi olmama, çevredeki insanların olumsuz tutumlarıyla baş etme, bakım ve eğitim masraflarının artması nedeniyle yaşanan ekonomik güçlükler, diğer aile gereksinimlerinin yeterince karşılanamaması ve utanç, üzüntü, hayal kırıklığı gibi birçok süreç aile üyelerinin stres yaşamasına neden olabilmektedir (Çiftçi Tekinarslan, 2010; Dyson, 1997; Havens, 2005; Küçüker, 2001; Metin, 2012). Özel gereksinimli çocuğa sahip ailelerin stres düzeylerinin eşler arasındaki ilişkiyi ve anne-baba, çocuk ilişkisini olumsuz yönde etkilediği de belirtilmektedir (Doğan, 2001; Dyson, 1993).

Yapılan araştırmalarda özel gereksinimli çocuğa sahip ailelerin stres düzeylerinin normal gelişim gösteren çocuğa sahip ailelerin stres düzeylerinden daha yüksek olduğu bulunmuştur (Dyson, 1997; Goldberg ve ark., 1986). Yetersizliğe sahip olan çocukların ailelerine; beklenen sorunlara yönelik başa çıkma yolları sunulduğunda, parasal yardım, materyal yardımı sağlandığında ve yakın çevresinden ve kurumlardan sosyal destek almaları sağlandığında ailelerin streslerinin azaldığı görülmüştür (Allen, Ciambrone ve Welch, 2000; Dunst ve Trivette, 1986). Ailelerin stres düzeyleriyle ilgili yapılan diğer araştırmalara bakıldığında, stres düzeyleri ile öz yetkinlik algıları arasında negatif bir ilişki bulunmuştur (Scheel ve Rieckmann, 1998). Benzer bir şekilde aile programlarına katlıp stres düzeyleri azalan ailelerin, öz yetkinlik algıları artmıştır (Jones ve Prinz, 2005).

Davranışların ve davranış değişikliklerinin ana belirleyicisi olarak tanımlanmakta olan öz yetkinlik, ailenin işlevlerini sağlıklı bir biçimde yerine getirmesinde önemli bir yere sahip olan; bilişsel, motivasyonel, duygusal ve seçim yapma süreçlerini etkilediği için önemlidir (Henson, 2001). Öz yetkinlik araştırmalarının bir bölümünü ebeveyn öz yetkinlik araştırmaları oluşturmaktadır. Aile özyetkinliği, ebeveynlerin çocuklarının davranış ve gelişimlerini pozitif yönde etkileme becerilerinin algısı olarak tanımlanmaktadır (Coleman ve Karraker, 1998; Junttila, 2010). Bandura (1997) ise ailenin öz yetkinliğinin ebeveynlerin şuandaki ve gelecekteki davranışları ile ilişkili olduğunu belirtmiştir. Öz yetkinliği yüksek olan ebeveynler çocuklarının ihtiyaçlarııın farkında olmakta, çocuklarının gelişimlerini izleyebilmekte, çocuklarıyla ilgili hizmet alımı seçimlerinde kendine güvenmekte ve çocuklarına daha fazla öğrenme firsatları tanımaktadırlar (Coleman ve Karraker, 2000; Hudson, Elek ve Fleck, 2001). Bu aileler problemlerle yüz yüze geldiğinde onlardan kaçmak yerine sorunun çözümüne odaklanmakta ve olumsuz duygu ve düşüncelerden kaçınmaktadırlar (Bandura, 1997). Dolayısıyla, ailenin öz yetkinliğinin çocuğun gelişimi üzerinde doğrudan etkisi vardır (Coleman ve Karraker, 1997).

Konuya ilişkin önceki çalışmalarda ailelerin öz yetkinliğini etkileyen faktörler araştrılmış ve bazı temel faktörler belirlenmiştir. Bu faktörler; aile davranışları ile çocuğun sosyal, duygusal ve gelişim özellikleridir. Aile davranışları ile çocukların gelişim özelikleri arasında güçlü bir bağ vardır (Guimond, Wilcox ve Lamorey, 2008). Yapılan araştırmalarda özel gereksinimli çocuğun doğumu ile ailelerin yaşadığı uyum zorlukları arasında bir bağ olduğu görülmüştür. Bu zorluklar çocukların yetersizlik derecesine göre değişir (Gross, Conrad, Fogg ve Wothke, 1994). Örneğin, gelişimsel gecikmesi olan çocukların ailelerinin öz yeterliliğini değerlendiren Crnic ve arkadaşları (1983) bu ailelerin normal gelişim gösteren çocuğa sahip ailelere göre; daha büyük oranda depresyon ve stres yaşadıklarını, çocuklarıyla daha fazla ilgilendiklerini, daha az eğlenceli vakit geçirdiklerini ve bunun sonucu olarak aile yeterlilik inançlarının daha düşük olduğunu bulmuşlardır. Otizmli çocuğa sahip ebeveynlerin öz yeterliliğini inceleyen Hastings ve Brown (2002) ise ebeveyn öz yetkinliğinin, ailenin endişe ve depresyon düzeyi ile çocuğun gelişimsel düzeyi arasında yönlendirici bir görev üstlendiğini belirtmiştir. Benzer şekilde araştrmalarda bu ebeveynlerin yüksek derecede endişe, depresif semptomlar, stres ve evlilikte fikir ayrılığı yaşadıkları rapor edilmiş ve bunların ailelerin öz yetkinlik inançlarını etkilediği bildirilmiştir (Crnic, 1983; Fishman, Wolf ve Noh, 1989; Sanders ve Morgan, 1997). Engelli çocuğa sahip aileler kendi yetenekleri ile ilgili öz-yetkinlik algısından yoksun olmaktadırlar ve bu ailelerin öz yetkinliğinin ebeveynlerin çocuk ile ilgili düşüncelerinden, demografik özelliklerden, sağlık durumlarından, almış olduğu desteklerden ve bebeğin mizacının zorluğundan etkilenmektedir (Barlow, Powell ve Gilchrist 2006; Guimond, Wilcox ve Lamorey, 2008).

Ebeveynlerin öz yetkinlik algılarıyla çocuğun gelişimin arasındaki ilişkiyi inceleyen çok az çalışma bulunmaktadır. Örneğin, Coleman ve Karraker (2003) yaptıkları araştrmada, annelik öz yetkinlik ölçeği ile Bayley Çocuklar İ̧in Gelişim Ölçeğinin puanlar arasında istatistiksel olarak olumlu ve anlamlı ilişkiler bulmuştur. Knoche, Givens ve Sheridan (2007) yaptıkları çalışmada annelerin depresyon ve ebeveyn öz yetkinlik düzeyleri ile bebeklerin Bayley Yenidoğan Gelişim 
Ölçeği'nden aldıkları puanları arasında anlamlı ilişkiler olduğunu belirtmiştir. Benzer şekilde, Swick ve Hassell (1990) ebeveynlerin öz yetkinlik inançları ile çocukların bütün gelişimsel alanlarının birbirleriyle ilişkili olduğunu bildirmişlerdir. Yetersizliğe sahip çocuğu olan ebeveynlerin öz yetkinliği ve çocuğun sosyal, duygusal ve özellikle gelişimsel sonuçları arasındaki ilişki ile daha çok ilgilenilmesi gerekmektedir (Guimond, Wilcox ve Lamorey, 2008). Bu bulgular neticesinde, çocukların sosyal duygusal ve gelişimsel alanları ile öz yetkinlik arasındaki ilişkiyi araştırmak ve öz yetkinlik inancını ölçmek önemlidir. Son yıllarda Türkiye'de öz yetkinlik üzerine birçok çalışma yapılmıştr. Bu çalışmalar; öz yetkinlik inançlarının akademik başarı ve performans üzerindeki etkilerini inceleme, öz yetkinlik inançlarının uzmanlık alanının seçimi ve meslek tercihlerine etkilerini inceleme ve öğretmenlerin öz yetkinlik inançları ile öğretimde gerçekleştirdikleri uygulamaları inceleme üzerine yoğunlaşmıştı. Özel gereksinimli çocuğa sahip ailelerin öz yetkinlik inançlarını değerlendirmeye yönelik çalışmaların ise oldukça sınırlı olduğu görülmektedir.

Kaner (2007) tarafindan yapılan araştırmada, engelli olmayan çocuğa sahip ebeveynlerin, çocukları engelli olan ebeveynlere göre yetkinlik inançlarının daha yüksek olduğu bulunmuştur. Diken ve Diken (2008) tarafindan yapılan araştırma sonuçlarına göre konuşmada gecikme yaşayan çocuklara sahip annelerin yüksek düzeyde öz-yetkinlik inancına sahip oldukları görülmüştür. Ayrıca kendilerini çoğu zaman yeterli hisseden annelerin kendilerini zaman zaman yeterli hisseden annelere göre daha fazla sözel iletişimin gelişmesine yönelik etkinlikler yaptı̆̆ı görülmüştür. Aksoy ve Diken (2009) ebeveynlerin (özellikle annelerin) öz yeterlik düzeyleri ile çocuklarının erken çocukluk dönemindeki gelişimleri arasındaki ilişkiyi inceleyen araştırmaları gözden geçirmiştir. Araştrrma sonucunda, annelerin sahip olduğu ebeveyn öz yeterlik algı düzeyi ile çocukların bilişsel, sosyal ve dil gelişimleri arasında ilişki olduğunu ve ebeveynlik öz yeterlik düzeylerinin sosyo-ekonomik durum, sosyal destekler, bekâr anne olma ve annelik yaşı gibi değişkenlerden etkilendiğini bildirmişlerdir. Telef (2013) engelli çocuğa sahip ebeveynlerin öz-yetkinlikleri ile psikolojik belirtiler (anksiyete, depresyon, olumsuz benlik, somatizasyon ve hostilite) arasındaki ilişkileri incelenmiştir. Çalışmada ebeveyn öz-yeterliği ile psikolojik belirtiler arasında negatif yönde anlamlı ilişkiler olduğu ve cinsiyete göre anlamlı fark olmadığı bulunmuştur. Eğitim düzeyi lise ve üniversite olan ebeveynlerin ebeveyn öz-yetkinlikleri eğitim düzeyi ilkokul olan ebeveynlerden daha yüksek olduğu görülmüştür.

Yetersizliği olan çocuğa sahip olan ailelerin bahsedilen zorluklara başa çıkabilmesi ve normal yaşamlarına devam edebilmeleri önemlidir. Bu noktada ailelerin yılmazlıkları da inmal edilmemelidir (Strnadová, 2006). Luthar ve Cicchetti (2000) yıımazlığı, bireylerin önemli sorun veya travma yaşantılarına rağmen olumlu bir uyum sergilediği bir süreç olarak tanımlarlar. Yılmazlık ailenin stresli durumlarla başa çıkabilme ve ailede dengeyi yeniden sağlayabilme becerisidir (McCubbin ve McCubbin, 1988, Patterson, 2002). Yılmazlık, ailelerin zorlu yaşam koşullarında başa çıkmada kilit rol oynamaktadır (Strnadová, 2006). Stranadová’ya göre yılmazlık düzeyi, ailelerin stres düzeylerinden, problem çözme becerilerinden, stres ile baş etme stratejilerinden, aile içi ilişkilerden ve aile kaynaklarından etkilenmektedir. Türkiye' de özel gereksinimli çocuğa sahip ailelerin yılmazlıklarını ele alan sınırlı sayıda araştırma bulunmaktadır. Bu araştırmalardan, İscan ve Malkoç (2017) tarafindan yapılan çalışmada, özel gereksinimli çocuğa sahip ailelerin umut düzeyleri, başa çıkma yeterlilikleri ve yılmazlık düzeyleri arasındaki ilişkiler incelenmiştir. Araştırma sonucunda, yılmazlık ve başa çıkma yeterliğinin birlikte umut üzerinde yordayıcı etkisinin olduğu saptanmıştır. Kaner, Bayraklı ve Güzeller (2011) tarafindan yapılan araştırmada normal gelişim gösteren çocuğa sahip anne-babaların yılmazlık düzeyleri zihinsel yetersizliği olan çocuğa sahip anne-babalara göre daha yüksek bulunmuştur. Bayraklı ve Kaner (2012) tarafindan yapılan araştırmada ise sosyal desteğin niceliği ve niteliği, problem odaklı basa çıkmayı olumlu yönde ve orta düzeyde, yılmazlığı ise düşük de olsa olumlu yönde; problem odaklı basa çıkma ise yılmazlığı olumlu yönde ve yüksek düzeyde etkilendiği bulunmuştur.

Toplumda anneler özel gereksinimi olan çocuklara daha duyarlı oldukları ve çocuklarını daha iyi tanıdıkları için (Kaner, 2004) bu araştırmada anneler ile çalışılmıştr. Araştırmanın, Türkiye'de özel gereksinimli çocuğa sahip olan ailelerin öz-yetkinlikleri, streslerini ve yılmazlık düzeyleri arasındaki ilişkiyi birlikte inceleyen ilk çalışma olması bakımından önemli olduğu düşünülmektedir. Çocuklara verilecek hizmetlerin etkili olabilmesi için, öncelikle ailenin gereksinimlerinin, aile işlevlerinin, yaşadığı zorlanmaların, başa çıkma mekanizmalarının ve bunların etkileşimlerinin çok boyutlu olarak incelenmesi müdahale ve eğitim hizmetlerinin planlanıp yürütülmesi için önemlidir (Kaner, 2004). Dolayısıyla bu araştırmanın sonuçlarının özel gereksinimli çocuğa sahip olan ailelerin öz yeterlilikleri, yılmazlıkları ve stres düzeyleri hakkında bilgi sahibi olmada ve bu çocuklara verilecek uygun destek ve eğitim hizmetlerin karşılanmasında yol gösterici olacağı umulmaktadır. Ülkemizde özel gereksinimli çocuğu olan/olmayan annelerin öz-yetkinlik ve yılmazlık düzeylerine yönelik öncü çalışmalardan biri olmasının yanı sıra bu annelerin öz-yetkinlikleri ve yılmazlıkları konusunda ülkemizde yapılacak yeni ve farklı çalışmalara veri sağlayacak olması bakımından da çalışmanın önem taşıdığına inanılmaktadır. 


\section{Yöntem}

Bu araştırmanın amacı, özel gereksinimli çocuğa sahip olan annelerin öz-yetkinlik inançları ve yılmazlık algılarının arasındaki ilişkiler ile gelir düzeyi ve annenin eğitim düzeyinin öz-yetkinlik, stres ve yılmazlık ile ilişkisini incelemektir.

\section{Araştırma Modeli}

Bu araştırma var olan durum değiştirilmeden, olduğu gibi betimlenmek istendiğinden iliş̧isel tarama modeli kullanılmıştı. Iliş̧kisel tarama modelleri, iki ve daha çok sayıdaki değişken arasında birlikte değişimin varlığını ve/veya derecesini belirlemeyi amaçlayan araştırma modelleridir (Karasar, 2009).

\section{Katilımcilar}

Araştırmanın çalışma grubunu Ankara ilinde bulunan özel gereksinimli çocuğa sahip olan toplam 150 anne oluşturmaktadır. Çalışma grubunda yer alan özel gereksinimli çocukların yaşları 3 ile 5 yaş arasında değişmekte olup, 30'u tam gün, 120'si yarım gün özel eğitim kurumlarına devam etmektedir. Özel gereksinimli öğrencilerin 42'si otizm, 63'si zihinsel engel, 9'u dil ve konuşma bozukluğu, 12'si işitme yetersizliği ve 24'ü ise başka türde bir tanıya sahiptir. Annelere demografik bilgiler Tablo 1'de verilmiştir.

Tablo1. Araştırmada Yer Alan Annelerin Demografik Özellikleri

\begin{tabular}{|c|c|c|c|}
\hline & & Sayı (n) & Yüzde (\%) \\
\hline \multirow{4}{*}{ Yaş } & 30 yaş ve alt & 49 & 32 \\
\hline & 31-35 yaş & 30 & 20 \\
\hline & $36-40$ yaş & 48 & 32 \\
\hline & 40 yaş ve üstü & 23 & 15 \\
\hline \multirow{5}{*}{ Eğitim düzeyi } & İlkokul & 62 & 40 \\
\hline & Ortaokul & 41 & 27 \\
\hline & Lise & 30 & 20 \\
\hline & Üniversite & 15 & 10 \\
\hline & Yüksek Lisans & 2 & 1 \\
\hline \multirow{2}{*}{ Medeni Hali } & Evli & 132 & 88 \\
\hline & Boşanmış & 18 & 12 \\
\hline \multirow{3}{*}{ Gelir Düzeyi } & Alt Gelir & 100 & 66 \\
\hline & Orta Gelir & 44 & 30 \\
\hline & Üst Gelir & 6 & 4 \\
\hline \multirow{2}{*}{ Anne İş } & Ev Kadını & 133 & 88 \\
\hline & Çalışıyor & 17 & 11 \\
\hline \multirow{3}{*}{ Çocuk sayısı } & 1 & 63 & 42 \\
\hline & 2 & 63 & 42 \\
\hline & 3 & 24 & 16 \\
\hline
\end{tabular}

\section{Veri Toplama Araçları}

\section{Bilgi formu}

Araşttrmada gereksinim duyulan aile ve çocuk özelliklerine ilişkin bilgileri edinebilmek için Bilgi Formu geliştirilmiştir. Araştırmacılar tarafindan geliştirilen bu form annenin yaşı, eğitimi, işi, ailedeki çocuk sayısı ile çocukların varsa tanısı ve yetersizlik derecesi, cinsiyeti, yaşı, mizacı, devam ettiği kurumu ve kurumuna devam ettiği süreye dair bilgilerden oluşmaktadır. Bilgi formunda yer alan sorular alanda çalışan üç akademisyenden uzman görüşü alınarak hazırlanmıştır.

\section{Aile Stresini Değerlendirme Ölçeği}

Holroyd (1974) tarafindan geliştirilen "Questionnaire on Resources and Stress - QRS" ölçeğinin Friedrich, Greenberg ve Crnic (1983) tarafindan geliştirilen kısa formundan (QRS-F) yararlanılmıştır. Aile Stresi Değerlendirme Ölçeği (ASDO) orjinali, 15 ölçekten ve 285 maddeden oluşan QRS'nın geniş bir yaş ranjındaki çocukların ailelerinin stres düzeylerini ölçmede yaygın olarak kullanıldığı görülmekledir. Küçüker (2001) tarafindan Aile Stres Değerlendirme Ölçeği (ASDO) adıyla Türkçe'ye çevrilen QRS-F'nın 05 yaş arası normal ve engelli çocuğa sahip anne babalardan oluşan bir örneklem grubu üzerinde geçerlik ve güvenirlik çalışması yapılmıştır. Araçtaki maddelere doğru-yanlış tipi yanıt verilmektedir. 
Araçtan yüksek puan almak stresin fazla olduğunu ifade etmektedir. Bu çalışma sonucunda 49 maddeden oluşan ölçeğin yapılan faktör analizi sonucunda "karamsarlık", "çocuğun işlevlerinde sınırlılık", "çocuğun özellikleri” ve "anne-babanın ve ailenin problemleri" olmak üzere dört faktörlü bir yapıya sahip olduğu görülmüştür. Normal ve engelli çocuk anne babalarından oluşan örneklem grubu için Cronbach alfa katsayısı tüm ölçek için 91, alt boyutlar için sılasıyla, 88. 87,73 ve 69 olarak bulunmuştur.

\section{Anne Yılmazlık Ölçeği-AYÖ}

Kaner ve Bayraklı (2010) tarafindan geliştirilen Anne Yılmazlık Ölçeği-AYÖ, toplam 37 maddeden dört alt ölçekten oluşmaktadır. Analizler sonucunda AYÖ’nden elde edilen alt ölçekler, alt ölçeklerin açıklamaları, içerdikleri maddelerin numaraları ve puanlama sistemi şu şekildedir: 1. Mücadelecilik-Meydan Okuma- Bu alt ölçek, güç koşullarla mücadele edebilme, zorlukların üstesinden gelebilme, olumsuz koşullara rağmen ayakta kalabilme ve risk alabilme gücüyle ilgili 17 maddeden oluşmaktadır 2. Öz-Yetkinlik- Öz-Yetkinlik alt ölçeğindeki maddeler bireylerin yaşamını etkili şekilde sürdürebilmesi için gerekli özellikleri ifade etmektedir ve dokuz maddeden oluşmaktadır 3. Yaşama Bağlılık- Bu alt ölçek yaşama olumlu bakışı ve yaşama olumlu katılımı ifade eden sekiz maddeyi içermektedir. 4. Kontrol- Üç maddeden oluşan alt ölçek bireyin yaşamını kontrol edebilmesini değerlendirmeyi amaçlamaktadır. AYÖ’nden yüksek puan almak annelerde yılmazlığın yüksek olduğunu ifade etmektedir (beni çok iyi tanımlıyor-5 puan, beni hiç tanımlamıyor-1puan). Ölçek maddelerine uygulanan madde analizi sonucunda elde edilen madde-toplam korelasyonları Mücadelecilik için 0.451-0.689, Öz-Yetkinlik için 0.468-0.697, Yaşama Bağlılık için 0.387-0.637 ve Kontrol için 0.339-0.408 arasındadır. Bu değerler ölçeğin tümü için 0.378-0.689 arasında değişmektedir. AYÖ’nün yapı geçerliği önce Temel Bileşenler Analiziyle incelenmiş, daha sonra ortaya çıkan yapıların doğruluğu Doğrulayıcı Faktor Analiziyle-DFA test edilmiştir. DFA sonucu elde edilen uyum indeks değerleri Kaykare/Sd=1300.96/620=2.1; RMSEA: 0.046; RMR: 0.044; NFI=0.84; NNFI: 0.90; CFI: 0.91; GFI: 0.88; AGFI: 0.87'dir (Kaner, Bayraklı ve Güzeller, 2011).

\section{Ebeveyn Öz Yetkinlik Ölçeği}

Guimond, Moore, Aier, Maxon, ve Diken (2005) tarafindan geliştirilen Yetersizliği Olan Çocukların Ebeveynleri İçin Öz yetkinlik Ölçeğinin (Parental Self-Efficacy Instrument for Children with Disabilities-PSICD) Cavkaytar, Aksoy ve Ardıç (2014) tarafindan yapılan Türkçe uyarlaması kullanılmıştır. Açımlayıcı faktör analizi yapılmadan önce ölçeği oluşturan maddelerin tamamı üzerinden madde toplam korelasyonuna ve Cronbach Alfa Katsayısına bakılmıştır. Cronbach alfa katsayısı ölçeği oluşturan 17 madde üzerinden .95 olarak bulunmuştur. Ölçeği oluşturan 17 maddenin tamamı üzerinden madde toplam korelasyonu yapıldığında maddelerin madde toplam korelasyonları .52 ile .83 arasında değişmektedir. Bu ölçekten yüksek puan almak annelerde öz yeterliğin yüksek olduğunu ifade etmektedir (kesinlikle kathlıyorum-5 puan, kesinlikle katılmıyorum-1puan). Faktör analizi yapılmadan önce maddeler arasında kısmi korelasyonların ve korelasyon matrisinin faktör analizi için uygun olup olmadığı Kaiser-Meyer-Olkin (KMO) katsayısı ve Bartlett Sphericity testi ile incelenmiştir. Yapılan analizlerde, 17 maddenin faktör analizi için KMO değerinin 0.95 olduğu görülmüştür. Analiz sonucuna bakıldığında, KMO değerinin istenilen minimum değerin oldukça üzerinde olduğu görülmektedir. KMO değerinin istenilen minimum değerin oldukça üzerinde olduğu görülmektedir. Benzer şekilde 17 maddenin Bartlett testi sonucu [x2= $3070.93 \mathrm{df=136,p<.001)]} \mathrm{olarak} \mathrm{bulunmuştur.} \mathrm{Ölçeğin} \mathrm{faktör} \mathrm{yapısını} \mathrm{belirleyebilmek} \mathrm{amacıyla} \mathrm{scree} \mathrm{plot}$ grafiği incelendiğinde, ölçeğin tek boyutlu bir yapı oluşturduğu görülmüştür (Cavkaytar, Aksoy ve Ardıç, 2014).

\section{Verilerin Analizi}

İstatiksel analizlere geçilmeden önce eksik veri incelemesi yapılmıştır. Yapılan inceleme sonucunda, "yerine ortalamayı koyma" yöntemine başvurulmuş ve incelenen maddeye ilişkin eksik verilerin yerine o maddeye ilişkin tam gözlemlerin ortalaması atanmıştır (Oğuzlar, 2010). Araştırma toplam ve alt faktör puanlarının normal dağılım gösterip göstermediklerinin anlaşılmasının amacıyla Normallik Testi uygulanmıştır. Grup büyüklüğü 50’den büyük olduğu için Kalmogorov-Smirnov normallik testi uygulanmıştır (Büyüköztürk, 2012). Analiz sonuçlarına göre (Tablo2), faktör puanlarının normal dağılım gösterdiği $(p>0,05)$ bulunmuştur. Özel gereksinimli çocuğu olan annelerin stres, öz-yetkinlik ve yılmazlıkları arasındaki ilişkileri belirlemek amacıyla Pearson Korelasyon analizi kullanılmıştır. Annelerin stres, öz yetkinlik ve yılmazlık algılarının gelir ve eğitim düzeyine göre farklılaşıp farklılaşmadığı ANOVA ile incelenmiştir. Yapılan analizler sonucunda elde edilen anlamlı farklılıkların kaynağını belirleyebilmek amacıyla post-hoc analizleri kullanılmıştır. Grupların varyanslarının homojenliği Levene's testiyle incelenmiş ve varyansların homojen olmaması nedeniyle gruplar arasında çoklu karşılaştırmalar Dunnet-C çoklu karşılaştırma tekniği ile gerçekleştirilmiştir. Gelir ve eğitim faktörlerinin annelerin yılmazlıkları, öz yetkinlikleri ve stres puanları üzerindeki etki büyüklerinin değerlendirilmesinde Green ve Salkind'in (2005) belirlemiş oldukları kesme noktaları dikkate alınmıştır. Bu kesme noktaları küçük, orta ve büyük olmak üzere sırasıyla .01, .06 ve .14 olarak kabul edilmektedir. 
Tablo 2. Toplam ve Alt Faktör Puanlarının Normallik Testi

\begin{tabular}{lcc}
\hline & \multicolumn{2}{c}{ Kolmogorov-Smirnov } \\
\cline { 2 - 3 } & İstatistik değeri & $\mathrm{p}$ \\
\hline Öz-yetkinlik toplam faktör puanı & 61 &, 38 \\
Yılmazlık toplam faktör puanı &, 64 &, 39 \\
Yılmazlık faktör 1 puanı &, 58 &, 077 \\
Yılmazlık faktör 2 puanı &, 092 &, 07 \\
Yılmazlık faktör 3 puanı &, 080 &, 08 \\
Yılmazlık faktör 4 puanı &, 128 &, 06 \\
Stres faktör 1 puanı &, 100 &, 05 \\
Stres faktör 2 puanı &, 149 &, 06 \\
Stres faktör 3 puanı &, 208 &, 05 \\
Stres faktör 4 puanı &, 178 &, 13 \\
Stres toplam faktör puanı &, 081 &, 17 \\
\hline
\end{tabular}

\section{Bulgular ve Yorumlar}

Tablo 3. Öz yetkinlik, Yılmazlık ve Stres ìle İlgili Betimsel Analizler

\begin{tabular}{lccccc}
\hline Değişkenler & $\mathrm{N}$ & Min. & Max. & $\bar{X}$ & s.d \\
\hline Stres & 150 & 1.20 & 1.96 & 1.5 & .11 \\
Öz-yeterlik & 150 & 1 & 3.94 & 2.6 & 1.56 \\
Yılmazlık & 150 & 2.09 & 4.85 & 2.5 & .62
\end{tabular}

Tablo 3’ deki sonuçlara bakıldığında annelerin stres ölçeğinden ortalama 1,5 puan aldığı görülmektedir. Stres ölçeğindeki maddelere doğru (1 puan) - yanlış (2 puan) tipi yanıt verilmektedir. Araçtan yüksek puan almak stresin fazla olduğunu ifade etmektedir. Dolayısıyla çalışmadaki annelerin daha fazla yanlış cevabı işaretledikleri ve stres düzeylerinin fazla olduğu görülmektedir. Öz-yeterlik ölçeğinde ise anneler 2,6 puan almıştır. Bu ölçekten yüksek puan almak annelerde öz yeterliğin yüksek olduğunu ifade etmektedir (5 puan -kesinlikle kathlıyorum, 1 puan kesinlikle katılmıyorum). Bu ölçekte annelerin daha çok katılmıyorum ile kısmen katılıyorum arasında cevap verdikleri görülmüştür. Başka bir ifadeyle annelerin öz-yeterlik düzeyleri düşük çıkmıştır. Annelerin yılmazlık puan ortalamaları ise 2,5 puan çıkmıştır. Bu ölçekten yüksek puan almak annelerde yılmazlığın yüksek olduğunu ifade etmektedir (beni çok iyi tanımlıyor-5 puan, beni hiç tanımlamıyor-1puan). Bu ölçekte de annelerin yılmazlık düzeyi düşük çıkmıştır.

Tablo 4. Özel Gereksinimli Çocuğu Olan Annelerin Stres, Öz-yetkinlik ve Yılmazlıkları Arasındaki İlişkiler

\begin{tabular}{|c|c|c|c|c|c|c|c|c|c|c|}
\hline & 2 & 3 & 4 & 5 & 6 & 7 & 8 & 9 & 10 & 11 \\
\hline Öz-yetkinlik toplam faktör puanı & $.75 * *$ & $.60 * *$ & $.72 * *$ & $.55^{* *}$ & .20 & -.22 & -.06 & -.15 & -11 & -.32 \\
\hline Yılmazlık toplam faktör puanı & & $.91^{* *}$ & $.88^{* *}$ & $.91^{* *}$ & .11 & .00 & .22 & .00 & .00 & $-.53 * *$ \\
\hline Yılmazlık faktör 1 (Mücadelecilik) puanı & & & $.66^{* *}$ & $.74 * *$ & $.67 * *$ & .037 & .18 & $-.60 * *$ & $-.71 * *$ & .04 \\
\hline Yılmazlık faktör 2 (Öz yetkinlik) puanı & & & & $.80 * *$ & $.73 * *$ & .049 & .20 & $-.46 *$ & $-.52 * *$ & -.03 \\
\hline Yılmazlık faktör 3 (Yaşama Bağlılık) puanı & & & & & $.70 * *$ & $.62^{*}$ & .23 & -.21 & .02 & -.01 \\
\hline Yılmazlık faktör 4 (Kontrol) puanı & & & & & & .016 & .15 & -.15 & -.00 & -.06 \\
\hline Stres toplam faktör puanı & & & & & & & $.82 * *$ & $.49 *$ & $.42 *$ & $.48^{*}$ \\
\hline Stres faktör 1 (karamsarlık)puanı & & & & & & & & .01 & .197 & .36 \\
\hline Stres faktör 2 (çocuğun işlevlerinde sınırlılık) puanı & & & & & & & & & .122 & -.04 \\
\hline Stres faktör 3 (çocuğun özellikleri) puanı & & & & & & & & & & .10 \\
\hline Stres faktör 4 (anne babanın ve ailenin problemleri) puanı & & & & & & & & & & 1 \\
\hline
\end{tabular}

Tablo 4 incelendiğinde, öz-yetkinlik toplam faktör puanı ile yılmazlık toplam faktör, yılmazlık faktör 1(mücadelecilik), yılmazlık faktör 2 (öz-yetkinlik) ve yılmazlık faktör 3 (yaşama bağlılık) puanları arasında ( $p<.001$ ) düzeyinde anlamlı ilişkiler bulunmuştur. Stresle toplam faktör ile tüm stres faktörleri arasında anlamlı ilişkiler ortaya çıkmıştır. Yılmazlık toplam faktör puanı, yılmazlık faktör 1 puanı (mücadelecilik), yılmazlık faktör 2 puanı (öz-yetkinlik) ve yılmazlık faktör 3 (yaşama bağlılık) puanları ile stres faktör 4 (anne babanın aile problemleri) puanları arasında anlamlı ilişkiler ortaya 
çıkmıştır. Öz yetkinlik ve stres arasında ise tüm faktör puanları arasında anlamlı ilişkiler bulunamamıştr.

Tablo 5. Öz yetkinlik, Stres ve Yılmazlık Faktörleri ile Ailelerin Sosyo-Ekonomik Düzeylerine ilişkin ANOVA Sonuçları

\begin{tabular}{llcccccccc}
\hline Bağımlı Değişkenler & Gelir Düzeyi & $\mathrm{n}$ & Ort. & $\mathrm{S}$ & $\mathrm{sd}$ & $\mathrm{F}$ & $\mathrm{p}$ & $\eta 2$ & Post Hoc \\
\hline \multirow{3}{*}{ Özyetkinlik } & Düşük & 100 & 90,71 & 30,06 & & & & & Orta>Alt, \\
& Orta & 44 & 102,65 & 20,84 & $2-149$ & 4.02 & .016 & .06 & Üst>Alt \\
& Yüksek & 6 & 73,16 & 47,29 & & & & & \\
\multirow{3}{*}{ Stres } & Düşük & 100 & 73,59 & 5,50 & & & & & \\
& Orta & 44 & 74,13 & 5,38 & $2-149$ & 4.03 & .020 & .06 & Üst>Alt \\
& Yüksek & 6 & 80,00 & 1,09 & & & & & \\
\hline \multirow{3}{*}{ Yılmazlık } & Düşük & 100 & 135,47 & 21,60 & & & & & Orta>Alt, \\
& Orta & 44 & 140,77 & 16,9 & $2-149$ & 3.07 & .049 & .040 & Üst>Alt \\
& Yüksek & 6 & 153,83 & 9,68 & & & & & Uns \\
\hline
\end{tabular}

Tablo 5 deki sonuçlara göre alt, orta ve üst gelir düzeyine sahip annelerin yılmazlıkları, öz yetkinlikleri ve stres toplam faktör puanları arasında $(p<.05)$ düzeyinde anlamlı ilişkiler bulunmuştur. Farklıkların hangi gruplar arasında olduğunu belirlemek için yapılan Post-Hoc sonuçlarına göre öz yetkinlik ve yılmazlık toplam faktör puanlarında alt gelir düzeyine sahip anneler ile orta ve üst gelir düzeyine sahip annelerin puanları arasında anlamlı farklıııklar oluşmuştur. Stres düzeyinde ise alt gelir düzeyine sahip annelerin stres düzeyi üst gelir düzeyine sahip annelerden anlamlı olarak daha düşük düzeyde çıkmıştr. Gelir düzeyine ilişkin etki büyüklüklerinin ise tüm alt alanlarda orta düzeyde olduğu görülmüştür.

Tablo 6. Öz-yeterlik, Stres ve Yılmazlık Faktörleri ile Ailelerin Eğitim Düzeylerine ilişskin ANOVA Sonuçları

\begin{tabular}{|c|c|c|c|c|c|c|c|c|}
\hline Bağımlı Değişkenler & Eğitim Düzeyi & $\mathrm{n}$ & Ort. & $\mathrm{S}$ & sd & $\mathrm{F}$ & $p$ & $\eta 2$ \\
\hline \multirow{4}{*}{ Öz yetkinlik } & illkokul & 63 & 88,3651 & 31,83 & \multirow{4}{*}{ 3-149 } & \multirow{4}{*}{4.39} & \multirow{4}{*}{.005} & \multirow{4}{*}{.083} \\
\hline & Ortaokul & 43 & 88,3651 & 32,73 & & & & \\
\hline & Lise & 28 & 103,5000 & 16,6 & & & & \\
\hline & Üniversite & 16 & 110,7500 & 6,02 & & & & \\
\hline \multirow{4}{*}{ Stres } & ilkokul & 63 & 74,1429 & 6,28 & \multirow{4}{*}{$3-149$} & \multirow{4}{*}{.34} & \multirow{4}{*}{.79} & \multirow{4}{*}{.007} \\
\hline & Ortaokul & 43 & 73,6512 & 4,47 & & & & \\
\hline & Lise & 28 & 73,6071 & 5,24 & & & & \\
\hline & Üniversite & 16 & 75,1250 & 5,23 & & & & \\
\hline \multirow{4}{*}{ Yılmazlık } & illkokul & 63 & 139,1111 & 19,37 & \multirow{4}{*}{$3-149$} & \multirow{4}{*}{2.05} & \multirow{4}{*}{.10} & \multirow{4}{*}{.041} \\
\hline & Ortaokul & 43 & 138,3023 & 20,53 & & & & \\
\hline & Lise & 28 & 130,0714 & 22,62 & & & & \\
\hline & Üniversite & 16 & 144,4375 & 16,83 & & & & \\
\hline
\end{tabular}

$$
{ }^{*} \mathrm{p}<.05 .{ }^{* *} \mathrm{p}<.001
$$

Tablo 6' daki sonuçlara göre annelerin eğitim düzeyi ile sadece annelerin öz yetkinlikleri arasında anlamlı farklılıklar bulunmuştur. Farklıkların hangi gruplar arasında olduğunu belirlemek için yapılan Post-Hoc sonuçlarına göre üniversite mezunu anneler ile ilkokul mezunu annelerin stres düzeyleri arasında anlamlı farklılıklar bulunmuştur.

\section{Tartışma}

Araştırmada ilk olarak özel gereksinimli çocuğa sahip annelerin stres, öz-yetkinlik ve yılmazlık ölçeklerinden aldıkları puanların betimsel analizleri yapılmıştır. Çalışmada, özel gereksinimli çocuğa sahip annelerin öz- yetkinliklerin, stres düzeylerinin ve yılmazlıklarının düşük düzeyde olduğu görülmüştür. Araştırmanın bu bulgusu, alanyazında incelenen araştrmalar tarafindan desteklenmektedir (Bootroydy, 1997; Hasting ve Brown, 2002; Kandari, 2005; Seybold, Fritz ve MacPhee, 1991; Kaner, Şekercioğlu ve Yellice-Yüksel 2007; Scheel ve Rieckmann 1998). Örneğin; Kaner, Şekercioğlu ve Yellice-Yüksel tarafindan yapılan çalışmada, zihinsel, işitsel, bedensel gibi farklı yetersizlik türlerine sahip çocukların annelerinin öz-yetkinlik inançlarının normal gelişen çocukların anne-babalarından daha düşük olduğunu bulmuştur. Boothroyd, (1997) ve Kandari, (2005) de yaptıkları çalışmada gelişimsel geriliği olan çocuklara sahip olan annelerin çocukların bakımıyla ilgili kendi yetenek ve kapasiteleri hakkındaki inançlarının düşük olmasından dolayı öz-yetkinlik algılarının düşük, stres düzeylerinin yüksek olduklarını bildirmişlerdir. Friborg, Hjemdal, Rosenvinge ve Martinussen, 2003; Kaner ve Bayraklı, 2010; Kaner, Bayraklı ve Güzeller, 2011 tarafindan yapılan araştırmalarda da özel gereksinimli çocuğa sahip olan annelerin yılmazlıkları daha düşük çıkmıştır. Özel gereksinimli çocuklara yönelik olumsuz tutumların,

| Kastamonu Eğitim Dergisi, 27(1), 2019| 
bu çocukların daha fazla bakıma ve ilgiye ihtiyaç duymalarının ve bu çocuklara nasıl bir gelecek beklediğine yönelik duyulan kaygıların ailelerin yılmazlıklarını, öz yetkinliklerini ve stres düzeylerini etkilediği belirtilmiştir (Kaner, 2009; Martinussen, 2003, Seybold, Fritz ve MacPhee, 1991).

Araştırmada ikinci olarak annelerin öz-yetkinlik, yılmazlık ve stres düzeyleri arasındaki ilişkilere bakılmıştı. Çalışma sonucunda annelerin yılmazlıkları ve öz- yetkinlikleri arasındaki genel olarak anlamlı ilişkiler ortaya çıkmıştı. Herhangi bir zorluk karşısında gösterilen öz-yetkinlik inançlarının bireyleri daha yılmaz yaptığı, yılmazlığın öz-yetkinlik inançlarını da içerdiği dolayısıyla öz-yetkinlik inancının yüksek olmasının yılmazlığı olumlu yönde artırdığı bilinmektedir (Rutter, 1987). Öz-yetkinlik inançlarını zayıf olarak değerlendiren anneler yüksek düzeyde stres yaşarlarken, yüksek yetkinlik inancı olan annelerin benliği aşağılayan yüklemelerden kaçındıkları ve daha az kaygı ve depresyon yaşadıkları bildirilmiştir (Kwok ve Wong, 2000). Bu çalışmada da özel gereksinimli çocuğa sahip annelerin stres düzeyleri ile öz yetkinlikleri arasında alanyazına benzer bir şekilde negatif bir ilişki bulanmakla beraber (Coleman ve Karraker, 2000; Jones ve Prinz, 2005; Scheel ve Rieckmann, 1998) stres alt faktörlerinden sadece çocuğun özellikleri alt faktörü ile öz-yetkinlik faktörleri arasında anlamlı ilişkiler ortaya çıkmıştır. Stres alt faktöründeki çocuğun özelliklerinde yer alan maddelere bakıldığında, bunların çocuğun işlevlerindeki yetersizliklerin yanı sıra, anne ve babaların çocuklarının toplumsal katılımlarına ilişkin yaşadıkları sıkıntıyı da ifade ettiği gözlenmektedir. Araştırma grubundaki özel gereksinimli çocukların özelliklerine bakacak olursak büyük bir kısmının zihinsel yetersizlik tanısı alan çocuklar oluşturmaktadır. Yapılan araştırmalarda engelli çocuk anneleri grubu içinde en fazla stres yaşayanların ve düşük öz-yetkinlik inançları olanların zihinsel engelli çocukların anneleri olduğu belirtilmiştir (Kaner, 2004; Rodriguez ve Murphy, 1997). Ayrıca, yetersizliği olan çocukların çevrede kabul görmemesi, hatta alay edilmesi, acınması, korkulması ve reddedilmesi gibi olumsuz tutum ve davranışlar yaşayabildikleri bunun sonucunda ailelerin yaşadıkları stresin artığı bildirmiştir (ÖziDA, 2009). Stres alt faktörlerinden olan çocuğun özellikleri ile öz-yetkinlik arasında diğer faktörlere göre anlamlı ilişkilerin çıkması bu nedenlerle açıklanabilir.

Çalışmada üçüncü olarak bağımlı değişkenlerin anne eğitim ve gelir düzeyi açısından anlamlı bir farklılık gösterip göstermediğine bakılmıştr. Yapılan analizler sonucunda geliri alt düzeyde olan anneler ile orta ve üst gelir grubundaki annelerin stres düzeyi, yılmazlıkları ve öz yetkinlikleri arasında anlamlı farklılıklar bulunmuştur. Etki büyüklerine bakıldığında ise gelir düzeyinin stres, yılmazlık ve öz yetkinlik üzerinde orta düzeyde etkisi olduğu görülmüştür. Öz- yetkinlikte ise üniversite mezunu anneler, ilkokul mezunu olan annelerden daha yetkin çıkmıştır. Bu bulgular ilgili alanyazın ile tutarlık göstermektedir. Yapılan araştırmalarda da gelir ve eğitim düzeyi yükseldikçe stresin azaldığı, öz yetkinlik ve yılmazlığın arttı̆ı bulunmuştur (Çakır, 2009; Gutman, 2008; Upadhyaya ve Havalappanavar, 2008). Özel gereksinimli çocuğa sahip olmanın ailelere ek yükler getirdiği bilinmektedir. Ailelerin engelli çocukları nedeniyle toplum tarafindan etiketlenmeleri, dışlanmaları çocuğun bakımı ve gelişimi ile ilgili yeterli bilgi düzeyine sahip olmamaları, eğitim düzeyinin düşük olması, ailelerin bir takım duygusal maddi ve sosyal kaynak gereksinimlerine intiyaç duymaları ve bunlara ulaşamamaları gibi pek çok olumsuz koşul bu ailelerde ortaya çıkan düşük öz-yetkinlik inançlarına neden olmaktadır (Coleman ve Karraker, 1997; Gutman, 2008; Seybold, Fritz ve MacPhee, 1991; Hassall, Rose ve McDonald, 2005). Dolayısıyla gelir ve eğitim düzeyleri düşük olan aileler tüm bu nedenlerden daha çok stres yaşamakta bu da ailelerin öz yetkinliklerini etkilemektedir.

Özel gereksinimli çocuğa sahip olan annelerin stres düzeylerinin azalmasında, öz-yetkinlik inançlarının ve yılmazlıklarının artmasında sosyal destekler sağlamanın etkili olduğu belirtilmiştir (Bayraklı 2010; Kaner, 2004; Mullins, 1987). Sosyal desteğin hangi türünün yararlı olduğu bireylerin içinde bulundukları koşullara göre değişmekte ve sosyal desteğin olumlu katkıda bulunabilmesi için, bireylerin gereksinimlerini karşılıyor olması gerekmektedir (Kaner, 2004). Ülkemizde yapılan çalışmalarda özel gereksinimli çocuğa sahip annelerin en çok bilgi düzeyinde gereksinimleri olduklarını bildirmişlerdir (Akçamete ve Kargın, 1996; Sucuoğlu, 1995). Bu nedenle, özel gereksinimli çocukların ailelerinin ne tür desteklere gereksinim duyduklarının belirlenmesi, devam ettiği kurumlarda ailelerin bu gereksinimlerinin karşılanması ailelerin çocukların yetersizlikleriyle ilgili zorluklarla başa çıkmasında yararlı olacaktır.

Engelli çocukların anneleri strese karşı daha savunmasızdır, ayrıca depresyon, sosyal izolasyon, evlilik uyumsuzluğu, derin üzüntü, kendini suçlama, çaresizlik, yetersizlik hissi, öfke, şok ve yorgunluk gibi etkenlerde daha yüksek risk altındadır (Gupta ve Singhal, 2005). Erken dönemde ailelerin yüksek düzeyde stres yaşaması ailelerin çocuk ile olan ilişkini etkilemekte ve çocuğun hayatın ilerleyen dönemlerinde bu ilişki daha da yetersiz hale gelmektedir. Dolayısıyla, ailelerin yaşadıkları stresi, öz-yetkinlik inançlarını ve yılmazııklarını anlamanın profesyoneller için büyük önemi vardır. Özel gereksinimli çocukların aileleri ile birlikte çalışanların bu değişkenleri anlamaları, bu aileleri değerlendirirken önemli bir bilgi sağlamaktadır. Bu sayede ailelerin strese karşı direnç becerilerinin geliştirmeleri sağlanabilir. Hâlihazırda önemli düzeyde stres yaşayan aileler için stres, öz-yetkinlik ve yılmazlık ile ilgili kilit bilgileri anlamak, ailelere yönelik müda- 
hale geliştirmede de önemlidir. Bu sonuçlar doğrultusunda, özel gereksinimli çocuğa sahip olan ailelere ilgili uzmanlar tarafindan danışmanlık hizmetlerinin verilmesinin ve ailelerin bir araya getirildikleri, duygularını ifade edebilecekleri sosyal destek gruplarının oluşturulmasının gerekli olduğu düşünülmektedir. Türkiye' de özel gereksinimli çocuğa sahip olan ailelerin stres, öz-yetkinlik ve yılmazlık düzeyleri gibi faktörlerinin aileler üzerindeki etkisini inceleyen sınırlı sayıda çalışma bulunmaktadır. Dolayısıyla bu alanlara yönelik çalışmaların artıııması ve araştırma sonuçlarının uygulamaya aktarılması için üniversiteler ile eğitim kurumları arasındaki ilişkilerin güçlendirilmesi önerilmektedir.

Araştırmanın sınırlılıklarına bakacak olursak, araştırma grupları, yetersizlik derecelerine göre göre eşleştirilmemiştir. Böyle bir eşleştirme yapılması öz-yetkinlik, stres ve yılmazlı̆ı̆n hangi faktörlerden etkilendiğini daha net ortaya koyacaktır. Araştırmadaki veriler annelerle görüşme yapılmadan değerlendirme araçlarının doğrudan annelere verilmesi şeklinde toplanmıştır. Yüz yüze görüşme ile elde edilecek verilerin daha geçerli ve güvenilir olacağı düşünülmektedir. Bu çalışmada sadece anneler yer almıştır. Yalnız anneler yerine, aile sistemi içerisinde yer alan tüm üyeleri (baba ve kardeşler) de içeren araştırmaların yapılmasının, bu alanı daha da zenginleştireceği düşünülmektedir.

\section{Kaynakça}

Akçamete, G., Kargın, T. (1996). İşitme engelli çocuğa sahip annelerin gereksinimlerinin belirlenmesi. Özel Eğitim Dergisi, 2 (2), 7-24.

Akkök, F. (1989) Özürlü bir çocuğa sahip anne babaların kaygı ve endişe düzeyini ölçme aracının güvenirlik ve geçerlik çalışması. Psikoloji Dergisi 7: $26-38$.

Allen, S. M., Ciambrone, D., Welch, L. C. (2000). Stage of life course and social support as a mediator of mood state among persons with disability. Journal of Aging and Health, 13 (3), 318-342.

Başbakanlık Özürlüler İdaresi Başkanlığı (ÖziDA), (2009), Toplum Özürlülüğü Nasıl Anlıyor? Ankara.

Bayraklı, H. (2010). Zihinsel engelli ve engelli olmayan çocuğa sahip annelerde yılmazlığa etki eden değişkenlerin incelenmesi. Yayınlanmamış yüksek lisans tezi, Ankara Üniversitesi Ankara.

Bayraklı, H. ve Kaner, S. (2012). Zihin engelli ve engelli olmayan çocuğa sahip annelerde yılmazlığa etki eden değişkenlerin incelenmesi. Kuram ve Uygulamada Eğitim Bilimleri, 12 (2), 1-18.

Boothroyd, R. A. (1997). Preliminary manual for the caregiver self-efficacy scale. Tampa, Florida: Department of Mental Health Law and Policy, University of South Florida.

Boyraz, G., \& Sayger, T.V. (2011). Psychological well-being among fathers of children with and without disabilities: The role of family cohesion, adaptability, and paternal self-Efficacy. American Journal of Men's Health, 5(4), 286-296.

Büyüköztürk, Ş. (2012). Sosyal Bilimler Için Veri Analizi El Kitabı: Istatistik, Araştırma Deseni, SPSS Uygulamaları ve Yorum. Ankara: PegemA Yayıncılık.

Campbell-Sills, L., Forde, D.R., \& Stein, M.B. (2009). Demographic and childhood environmental predictors of resilience in a community sample. Journal of Psychiatric Research, 43, 1007-1012.

Cavkaytar, Aksoy ve Ardıç (2014) Aile Gereksinimlerini Belirleme Aracının Geçerlik ve Güvenirliğinin Güncellenmesi. Ankara Üniversitesi Eğitim Bilimleri Fakültesi Özel Eğitim Dergisi 2014, 15(2) 1-12.

Cohen, J. (1988). Statistical power analysis for the behavioral sciences, Second Edition. Hillsdale, New Jersey: Lawrence Erlbaum Associates.

Coleman, P.K. ve Karraker, K.H. (1997). Self Efficacy and Parenting Quality Findings and Future Applications. Developmental Review, $18,47-85$.

Çakır, S. G. (2009). Factors and mechanisms of resilience among Turkish migrant women in the UK. Yayınlanmamış doktora tezi, Ortadoğu Teknik Üniversitesi, Ankara.

Doğan, M. (2001). Iş̧itme engelli çocuğa sahip ebeveynlerin çeşitli psikolojik değişkenler açısından değerlendirilmesi. Yayınlanmamış yüksek lisans tezi, Ankara Üniversitesi, Ankara.

Dunst, C. J., Trivette, C. M. (1986). Mediating influences of social support: personal, family, and child outcomes. American Journal of Mental Defiency, 90 (4), 403-417.

Duygun, T. (2001). Zihinsel engelli ve sağlıklı çocuk annelerinde stres belirtileri, stresle başa çıkma tarzları ve algılanan sosyal desteğin tükenmişlik üzerine olan etkisi. Yayınlanmamış yüksek lisans tezi, Ankara Üniversitesi, Ankara.

Dyson, L. L. (1993). Responce to the presence of a child with disabilities: Parental stress and family functioning over time. American Journal on Mental Retardation, 98 (2), 207- 218.

Dyson, L. L. (1997). Fathers and mothers of school-age children with developmental disabilities: pavental stress, family functioning, and social support. American Journal on Mental Retardation, 102 (3), 267-279.

Goldberg, S., Marcovitch, S., MacGregor, D., Lojkasek, M. (1986). Family responses to developmentally delayed preschoolers: etiology and the father's role. American Journal on Mental Deficiency, 90 (6), 610-617.

Guimond, A. B., Wilcox, M.J., \& Lamorey, S.G. (2008). The Early Intervention Parenting Self-Efficacy Scale (EIPSES) Scale Construction and Initial Psy-chometric Evidence. Journal of Early Intervention, Vol. 30, Number 4, 295-320.

Gutman, L. M. (2008). Social and emotional development in infancy and early childhood. Benson, J. B., Haith, M. M.(Eds) Risk and resilience, (pp.24- 34). University of London, UK: Elsevier Inc.

| Kastamonu Eğitim Dergisi, 27(1), 2019| 
Friedrich, W. N., Greenberg, M. T., Crnic, K. (1983). A short form of the questionnaire onresources and stress. American Journal on Mental Deficiency, 88 (1), 41-48.

Friborg, O., Hjemdal, O., Rosenvinge, J. H., \& Martinussen, M. (2003). A new rating scale for adult resilience: What are the central protective resources behind health adjustment? International Journal of Methods in Psychiatric Research, 12(2), 65-76.

Hassall, R., Rose J., \& McDonald, J. (2005). Parenting stress in mothers of children with an intellectual disability: the effects of parental cognitions in relation to child characteristics and family support. Journal of Intellectual Disability Research, 49(6), 405-418.

Hastings, R., \& Brown, T. (2002). Behavior problems of children with autism, parental self-efficacy, and mental health. American Journal on Mental Retardation, 107(3), 222-232.

Havens, C.A. ( 2005). Becoming a Resilient Family: Child Disability and the Family System. National Center on Accessibility. Access Today, Spring 2005. Special Volume, Issue 17.http://www.indiana.edu/nca/monographs/17family.shtml

Holroyd, J. (1974). The questionnaire on resources and stress: An instrument to measure family response to a handicapped family member. Journal of Community Psychology, 2, 92-94.

Jones, T. L., \& Prinz, R. J. (2005). Potential roles of parental self-efficacy in parent and child adjustment: A review. Clinical Psychology Review, 25(3), 341-363.

Kandari, H. Y. (2005). Parenting stressors, needs for services, and caregiving self-efficacy among mothers of children with mild IDD in Kuwait: Assessing impact between variables. Unpublished doctoral dissertation, Simmons College, Boston.

Kaner, S. ve Bayraklı, H. (2009). Engelli ve engelli olmayan çocuklu annelerde yılmazlık, sosyal destek ve stresle başa çıkma becerileri. Eğitim Bilimleri ve Uygulama Dergisi, 8(15), 115-133.

Kaner, S. ve Bayraklı, H. (2010b). Aile Yılmazlık Ölçeği: Geliştirilmesi, geçerlik ve güvenirliği. Ankara Üniversitesi Eğitim Bilimleri Fakültesi Özel Eğitim Dergisi, 11 (2), 47-62.

Kaner, S., Bayrakli, H. ve Güzeller, C.O. (2011). Anne-babaların yılmazlık algılarının bazı değişkenler açısından incelenmesi. Özel Eğitim Dergisi, 12(2),63-78.

Karasar, N. (2009). Bilimsel araştırma yöntemi. Ankara: Nobel Yayınları.

Küçüker, S. (1997). Bilgi verici psikolojik danışmanlık programının zihinsel özürlü çocukların kardeşlerinin özürle ilgili bilgi düzeylerine ve özürlü kardeşlerine yönelik tutumlarına etkisi. Yayınlanmamış doktora tezi, Ankara Üniversitesi, Ankara

Küçüker, S. (2001). Küçük adımlar erken eğitim programının gelişimsel geriliği olan çocuğa sahip anne-babaların stres ve depresyon düzeyleri üzerindeki etkisinin incelenmesi (77-104), Küçük adımlar erken eğitim programı. İstanbul: Zihinsel Engelliler Destek Derneği.

Kwok, S. \& Wong, D. (2000). Mental health of parents with young children in Hong Kong: the roles of parnting stress and parenting self-efficacy. Child and Family Social Work 5, 57-65.

McCubbin, H. I. and McCubbin, M. A. (1988). Typologies of Resilient Families: Emerging Roles of Social Class and Ethnicity. Family Relations, 37, 247-254.

Mullins, J. B. (1987). Authentic Voices From Parents of Exceptional Children. Family Relations, 36, 30-33.

Oğuzlar, A. (2010). Alan Araştırmalarında Kayıp Değer Problemi ve Çözüm Önerileri. 29 Aralık 2014 tarihinde http://idari.cu.edu.tr/sempozyum/bil51.htm adresinden alınmıştir.

Scheel, M. J., \& Rieckmann, T. (1998). An empirically derived description of selfefficacy and empowerment for parents of children identified as psychologically disordered. American Journal of Family Therapy, 26(1), 15-27.

Seybold, J., Fritz, J., \& MacPhee, D. (1991). Relation of social support to the selfperceptions of mothers with delayed children. Journal of Community Psychology, 19(1), 29-36.

Sucuoğlu, B. (1995). Özürlü çocuğu olan anne babaların gereksinimlerinin belirlenmesi. Çocuk ve Gençlik Ruh Sağlığı Dergisi, 2(1), $10-18$.

Patterson, J.M. (2002). Intergtating Family Resilience and Family Stress Theory. Journal of Marriage and Family, 64, 349-360.

Rodriguez, C.M. ve Murphy, L.E.(1997). Parenting stress and abuse potential in mothers of children with developmental disabilities. Child Maltreatment. (3): 245-252, 1997.

Rutter, M. (1987). Psychosocial resilience and protective mechanisms. The American Journal of Orthopsychiatry, 57 (3), $316-331$.

Tsibidaki, A., \& Tsamparli, A. (2009). Adaptability and cohesion of Greek families: raising a child with a severe disability on the island of Rhodes. Journal of Family Studies, 15, 245-259.

Upadhyaya, G., ve Havalappanavar, N.B. (2008). Stress in parents of the mentally challenged. Journal of the Indian Academy of Applied Psychology, 34: 53-55 